\title{
GAP ANALYSIS OF THE QUALITY OF SALES SERVICE
}

\author{
Š. Kala, L. Vokáčová, J. Huml \\ Received: December 17, 2010
}

\begin{abstract}
KALA, Š., VOKÁČOVÁ, L., HUML, J.: Gap analysis of the quality of sales service. Acta univ. agric. et silvic. Mendel. Brun., 2011, LIX, No. 2, pp. 137-142

The article aims to measure the size of customer gaps as for their perception of sales service standard quality. Gap analysis employed for customer gap measurement is elaborated on the basis of the results obtained from questionnaire enquiry directed on customers and employers of the company sales places that were under examination. Questionnaire enquiry revealed substantial disparity between the perception of standard by employers and customers, especially in terms of sales personnel contact with customer. The research has quantified the size of customer gaps within sales service quality standard categories. In addition, it identifies problem areas detected by means of the carried out analysis as well as it provides suggestions for their solution.
\end{abstract}

customer gaps, sales service quality standard, sales personnel

In the course of the last decade the service sector has achieved significant progress as for service quality improvement (Reichheld, 2001). This phenomenon makes many enterprises interested in attaining and retaining high level of service quality. As Levy states (1995), a great deal of subjects that operate their own distribution network show strong inclination toward service quality improvement. This trend is nevertheless prominent especially with those distributors whose primary aim is to gain competitive advantage in future. These days, distributors are more than ever regarded as service providers and they are thus forced to meet the requirements that customers have in terms of the quality of the provided service.

Enterprises engaged in the distribution differ from other kinds of enterprises by offering to their customers mix of products and services. However, not all distribution enterprises can be regarded as identical. On the contrary, there are differences among particular kinds of these enterprises. These differences may be then have impact on the evaluation of service quality within the given distribution enterprise and it is therefore necessary to carry out service quality research across a wide range of different distribution enterprises.
The subject of the research is represented by DEKTRADE Inc. whose main activity is focused on the sale of construction materials. Other activities involve production of own range of construction material Dek as "private label". DEKTRADE Company was established in 1993, it currently has 1100 employees and sales network offers 58 branches in the Czech Republic and Slovakia. With the turnover of more than 6 mld. CZK it is the biggest supplier of construction materials in the Czech Republic. Customer portfolio reveals that $43 \%$ share in the company turnover have big construction companies, 18\% smaller construction companies, 14\% individual customers and investors, $13 \%$ insulation specialists and $12 \%$ roof tilers (www.dek.cz).

\section{METHODS AND RESOURCES}

technical literature dealing with the issue of service quality allows only marginal space as for the role of sales personnel and its influence on service quality. According to Lewis and Entwistle (1990) sales personnel exerts substantial influence on customers and the level of its professionalism thus represents fundamental constituent as for the quality of the service provided to customer who perceived 
its mediation in a certain way. This conclusion results from the fact that there is direct interaction between customer and sales personnel immediately after customer's entry to the sales place. These interactions become the straightforward evidence predicating about the existence of service and during its delivery sales personnel plays an indispensable role (Czepiel, 1990; Suprenant, Solomon, 1996).

Since the enterprise system and the service quality management system representing its integral part relates to both customer and sales personnel it is important to consider both groups within the research (Bitner, Booms and Mohr, 1994). Czepiel (1990) states that the simultaneous analysis of customer and sales personnel attitude would enable to identify any disparities and to determine areas of potential improvement. Distribution subjects may then use these findings of possible disparities in order to ensure appropriate improvement of sales personnel attitude.

The problem of service quality systematization as well as the definition and the way of service quality measurement was first approached by Parasuraman, Zeithaml and Berry (1990). These authors developed Gap model of service quality that represents a commonly employed instrument for service quality measurement. The model is based on the assumption that customer first formulates some expectations in relation to particular aspects of the provided service and that he takes notice of the process of service delivery itself and finally that he perceives the whole performance in a certain way.

For the evaluation of service quality, consumers employ some specific criteria that fall within five large areas that are applied during the categorization of customer expectations (Zeithaml, Parasuraman, Berry, 1990):

Tangible aspects - the appearance of physical accessories, equipment, personnel and communication material,

Reliability - ability to perform the given service properly and accurately,

Perceptivity - willingness to help customers and to be immediately at their disposal,

Assurance - knowledgeable and polite employees able to induce confidence,

Empathy - kindness, attention paid to every single customer.

Gap model of service quality endeavours to identify the factors which influence service quality and it tries to reveal possible shortcomings or "gaps" that may occur during the process of service delivery ${ }^{1}$.
"Gaps" occur provided that there is discrepancy between customer expectation and the actually perceived level of the obtained service (Zeithaml, Parasuraman, Berry, 1990).

Some authors presume that the measurement of employees' perception (performance) may represent more adequate way of service quality measurement (Cronin, 2000). Research among employees allows employees themselves to formulate their own opinion as for what services are provided and how they are evaluated on the part of customers. Proposals concerning increased effectiveness of service delivery that may be suggested by personnel play a crucial role as for service quality improvement (Palmer, 2001).

However, there may be discrepancies between consumer expectation and service provider perception. It means that service provider may not always correctly identify what criteria consumer associates with high quality, what elements the given service should include in order to satisfy consumers' needs and what level of the realization of these elements is necessary so that the service would be perceived as having high quality (Zeithaml, Parasuraman, Berry, 1990).

The absence of measurement would prevent managers' form identifying their companies' or products' current position and they would be unable to find out whether their objectives have been met. Measurement requires careful definition. Quality and profitability represent two intertwined ways leading to the creation of values for both customers and society. In the broader sense, quality focuses at advantages that are produced in favour of customers. Profitability relates to company expended costs. These costs may have significant influence on the service price quotation for customer (Lovelock, 2001).

For the purposes of the solution of the defined problem descriptive research by means of questioning was carried out. Enquiring proceeded in eight selected DEKTRADE sales places in the Central Bohemian Region and in Prague: Benešov, Kladno, Beroun, Kolín, Mladá Boleslav, Praha-Zličín, Praha-Malešice, Praha-Kunratice. These sales places were chosen intentionally especially with the view of good accessibility (heavy concentration of branches), and affordable temporal and financial capacities expended for the research.

The starting point of the carried out research represented the pre-research of the verification of the service quality standard criteria description (in to-

1 Model deals with five different gaps: Gap 1: Gap between customer expectations - management perception; Gap 2: Gap between management perception - service quality specification; Gap: Gap between service quality specification - service delivery; Gap 4: Gap between service delivery - external communication; Gap 5: Gap between customer expectation and performance perception. 
tal 37 aspects/criteria divided into the so-called categorial areas were verified ${ }^{2}$ ) during which controlled interviews revealed the degree of correspondence and relevance of individual service quality standard criteria.

The pre-research results allowed the elaboration of two questionnaires (for customers and for employees) whereas each contained 37 questions made up according to criteria of the suggested service quality standard including verbal description. Both groups of respondents made declarations as to the presented text of the standard and noted down two facts in the questionnaire as follows:

- the degree of her/his agreement with the formulation of individual criteria in relation to service quality - for this purpose Likert scale was employed (HDA = high degree of agreement, MDA = middle degree of agreement, $\mathrm{NO}=$ no opinion, $\mathrm{MDD}=$ middle degree of disagreement, HDD = high degree of disagreement),

- the relevance of a criterion for purchase process ${ }^{3}$ - for this purpose semantic differential, i.e. relevance scale was employed ( 1 = very relevant, $2=$ relevant, $3=$ neutral relevance, $4=$ not relevant, $5=$ very irrelevant).
Example of question (criterion) formulation along with evaluation sheet demonstrates the following figure (see Fig. 1).

Questions of identification character were in the case of customer research focused on sex, age, type of customer and frequency of purchase. Employee research was centred on sex, age, work position.

For the questioning purposes two groups of respondents of the preset number of participants were put together. The size of customer sample was 200 respondents, and the size of the sample with DEKTRADE sales places employees was 48 respondents. Determination of the preset number of the filled in questionnaires was used especially on the grounds of ensuring balance and well-proportionality of individual sales places respondent representatives within the scope of the research.

\section{RESULTS AND DISCUSSION}

The individual criteria were interpreted within the framework of evaluation by the average value obtained from the acquired data ${ }^{4}$ (customer research presented 201 respondent questions on a given criterion, and employee research presented 48 respon-

HDA - high agreement MDA - middle agreement NO - no opinion MDD - middle disagreement HDD - high disagreement

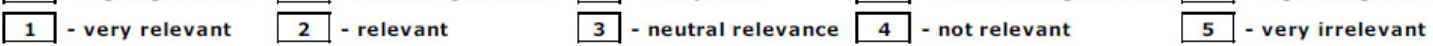

37) REQUISITION OF CUSTOMER CONTACT Sales personnel (regional representative in particular) demands the contact on customer in the form of visiting card, telephone number, or email address etc. the degree of agreement with the formuation of criteria VS SS NN SN VN the relevance of a criterion

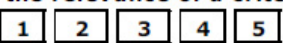

1: Example of question in questionnaire

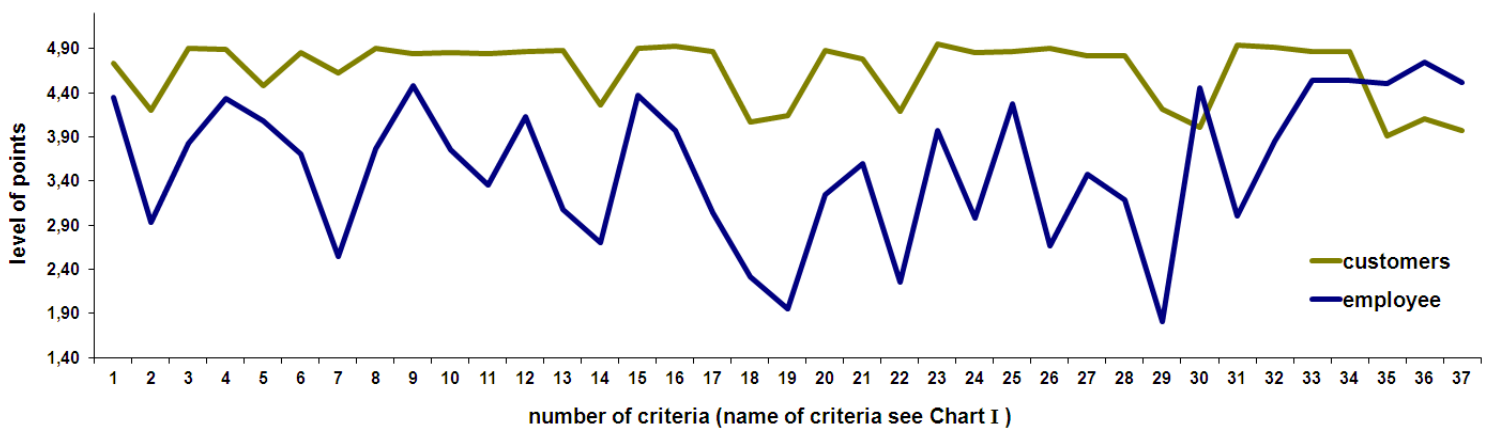

2: Research results indicating the degree of customer and employee agreement

2 Categorial areas represent functional areas of the given criterion. It concerns the following 8 categories (generally applicable for sales network of wide range of sectors): surroundings of sales place; interior of sales place; sales personnel contact with customer; detection of customer's needs; choice of suitable purchase solution; form of offer presentation; end of negotiation with customer.

3 In the case of employee research respondents described the way they perceive the relevance of criteria formulations for customer during her/his purchase process.

4 For the interpretation of results as for the degree of agreement with standard criteria the following adjusting interpretation was employed: $\mathrm{HDA}=5$ points, $\mathrm{HDD}=1$ point. For the interpretation of results as for the degree of standard criterion relevance the reverse orientation value scale was employed: very relevant $1=5$ points, very irrelevant $5=1$ point. 


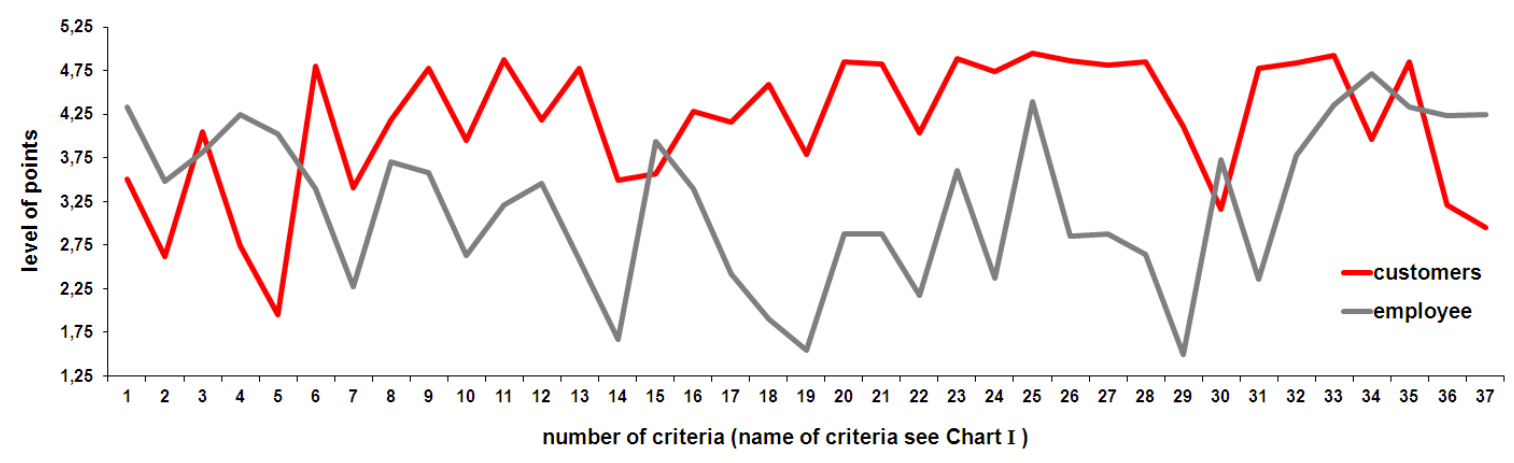

3: Research results indicating the degree of relevance with customers and employees

dent questions). Research data are illustrated in the following graphs (see Fig. 2 and 3).

Figures 2 and 3 clearly manifest considerable difference in perception of individual standard criteria between customers and the company represented by sales place employees.

Results of questioning of both respondent groups - customer and employee - are also entered in the chart (see Chart I).

The chart demonstrates the different results of customer and employee research that is further interpreted by means of percentage representation. Only four criteria (No. 30, 35, 36, 37) showed the degree of agreement with criterion higher with employees than with customers.

The above mentioned research results lead to the conclusion that customer group of respondents declared their agreement with criteria formulations in the suggested standard. Respondent's agreements move within the interval 3.92-4.69 point, which may be interpreted as middle up to high degree of agreement with the formulation of service quality standard. Text of the standard was thus confirmed.

The degree of relevance was in nine cases (with the criterion No. 1, 2, 4. 5, 15, 30, 34, 36, 37) higher with employees than with customers. These criteria illustrate that employees overestimate the given criterion in relation to customer purchase process. The remaining criteria show that the degree of relevance was higher with customer group of respondents than with employees and it is possible to state that in these cases employees tend to underestimate the relevance of the given criteria.

The overall result of the degree of agreement and the degree of relevance of both customer and employee research is expressed by the average value of both respondent groups. The total value of the degree of agreement with customer group of respondents was expressed by 4.65 points whereas this result may be interpreted as very satisfactory. These findings confirm that customers agree with the formulation of individual criteria. With employee group of respondents the total value of the degree of agreement with criteria was expressed by 3.58 points. The detected values of the degree of agreement enable us to determine the total size of customer gap, i.e. the difference between the perception of customers and sales place employees. This gap amounts to 1.07 points, which in percentage representation gives $26.75 \%$. It can be thus concluded that sales place employees do not share the same view with customer as for the solution of the given situation provided in standard. This can be regarded as unfavourable since customer-oriented forms bring closer their activities and attitudes toward customers.

The total value of the degree of criteria relevance for customer is expressed by 4.14 points. On the basis of the obtained findings it can be stated that customers consider the suggested standard as relevant. The employee group of respondents expressed the total value of the degree of criteria relevance by 3.23 points. The detected values of the degree of relevance allow us to express the total size of employee gap, i.e. the difference between the perception of customers and sales place employees. This gap amounts to 0.91 points, which in percentage representation gives $22.75 \%$. It can be thus concluded that sales place employees do not share the same view with customer as for the relevance of the solution of the given situation provided in standard, which can be regarded as unfavourable state. 


\begin{tabular}{|c|c|c|c|c|c|c|c|c|c|}
\hline 疍 & name of criteria & 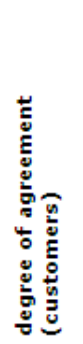 & 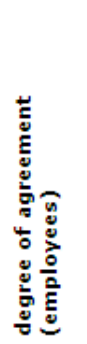 & 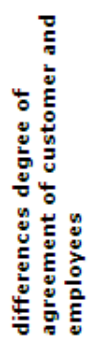 & 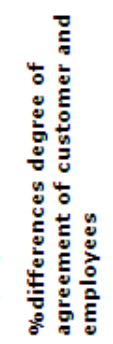 & 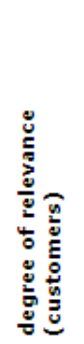 & 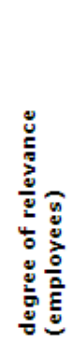 & 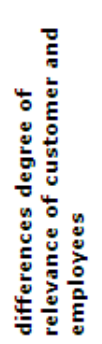 & 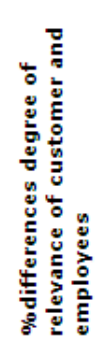 \\
\hline & Driveway directory boards, advertising boards & 4.73 & 4.35 & 0.38 & $9.43 \%$ & 3.51 & 4.33 & -0.83 & $20.65 \%$ \\
\hline & Neatness of surrounding areas & 4.20 & 2.94 & 1.26 & $31.54 \%$ & 2.62 & 3.48 & -0.86 & $-21.56 \%$ \\
\hline & Exterior look of salesroom & $4.91 \mathrm{~s}$ & 3.83: & 1.07 & $26.80 \%$ & 4.05 & 3.81 & 0.24 & $5.93 \%$ \\
\hline & $\begin{array}{l}\text { Identificarion elements - logos, boar } \\
\text { sales place name }\end{array}$ & 4.89 & 4.33 & 0.56 & $13.93 \%$ & 2.75 & 4.25 & -1.51 & $37.84 \%$ \\
\hline & Flags with DEKTRADE logo & 4.48 & 4.83 & 0.40 & $9.98 \%$ & 1.95 & 4.02 & -2.08 & $51.89 \%$ \\
\hline 6 & Car park for clients & 4.85 & 3.711 & 1.14 & $28.56 \%$ & 4.81 & 3.40 & 1.41 & $35.25 \%$ \\
\hline & pany cars & 4.63 & 2.54 & 2.09 & $52.13 \%$ & 3.41 & 2.27 & 1.14 & \\
\hline & iotional roof tiles & 4.91 & 3.77 & 1.14 & $28.49 \%$ & 4.19 & 3.71 & 0.48 & $12.02 \%$ \\
\hline & GeI & 4.85 & 4.78 & 0.37 & & 4.78 & 3.58 & 1.20 & \\
\hline 10 & Clean & 4.85 & 3.75 & 1.10 & & 3.95 & 2.63 & 1.33 & \\
\hline 11 & Mark & 4.85 & 3.35 & 1.49 & $37.29 \%$ & 4.88 & 3.21 & 1.67 & \\
\hline 12 & Cop & 4.87 & 4.13 & 0.74 & $18.52 \%$ & 4.18 & 3.46 & 0.72 & \\
\hline 13 & $\begin{array}{l}\text { Completenes } \\
\text { materials }\end{array}$ & 4.89 & 3.08 & 1.80 & $45.06 \%$ & 4.77 & 2.58 & 2.19 & $54.70 \%$ \\
\hline 14 & Waste bins & 4.26 & 2.71 & 1.55 & $38.76 \%$ & 3.49 & 1.67 & 1.83 & $45.65 \%$ \\
\hline 15 & Safe & 4.91 & 4.36 & 0.53 & $13.26 \%$ & 3.57 & 3.94 & -0.37 & $.13 \%$ \\
\hline 16 & $\begin{array}{l}\text { Location and realization of product } \\
\text { banners }\end{array}$ & 4.93 & 3.98 & 0.95 & $23.66 \%$ & 4.29 & 3.40 & 0.89 & $22.32 \%$ \\
\hline 17 & Suita & 4.87 & 3.04 & 1.83 & $45.73 \%$ & 4.16 & 2.42 & 1.74 & $43.56 \%$ \\
\hline 18 & & 4.07 & 2.31 & 6 & & 4.60 & & & \\
\hline 19 & Empl & 4.14 & 1.96 & 2.19 & & 3.79 & 1.54 & 2.24 & \\
\hline 20 & Com & 4.88 & 3.25 & 1.63 & $40.64 \%$ & 4.85 & 2.88 & 1.97 & $49.27 \%$ \\
\hline 21 & $\begin{array}{l}\text { Inte } \\
\text { addr }\end{array}$ & 4.78 & $\overrightarrow{3.60}$ & 1.18 & $29.42 \%$ & 4.83 & 2.88 & 1.96 & $48.90 \%$ \\
\hline 22 & & 4.19 & 2.25 & 1.94 & $48.60 \%$ & 4.03 & 2.17 & 1.87 & $46.70 \%$ \\
\hline 23 & & 96 & 3.98 & .98 & & 4.89 & & & \\
\hline 24 & & & 2.98 & 1.8 & & 4.74 & 2.38 & 2.36 & \\
\hline 25 & & 4.87 & 4.27 & 0.59 & & 4.95 & & 0.55 & \\
\hline 26 & Askin & & 2.67 & 2.23 & & 4.86 & 2.85 & 2.01 & \\
\hline 27 & Attentiv & 4.82 & 3.48 & 1.34 & $33.54 \%$ & 4.82 & 2.88 & 1.94 & $48.52 \%$ \\
\hline 28 & $\begin{array}{l}\text { Formula } \\
\text { respect }\end{array}$ & 4.83 & 3.19 & 1.64 & $40.96 \%$ & 4.85 & 2.65 & 2.20 & $55.00 \%$ \\
\hline 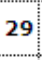 & $\begin{array}{l}\text { Summary of } \\
\text { customer's } \mathrm{n}\end{array}$ & 4.21 & 1.81 & 2.40 & $60.04 \%$ & 4.11 & 1.50 & 2.61 & $65.24 \%$ \\
\hline 30 & $\begin{array}{l}\text { Process of comparison of DEK } \\
\text { competition }\end{array}$ & 4.01 & 4.46 & -0.44 & $11.09 \%$ & 3.15 & 3.73 & -0.57 & 14.37 \\
\hline 31 & $\begin{array}{l}\text { Ability to make us } \\
\text { condition goods o }\end{array}$ & 4.95 & 3.00 & 1.95 & $48.63 \%$ & 4.77 & 2.35 & 2.42 & $60.42 \%$ \\
\hline 32 & Ability of argume & 4.92 & 3.85 & 1.07 & $26.66 \%$ & 4.84 & 3.77 & 1.07 & $26.75 \%$ \\
\hline 33 & & & & & & & 4.35 & 0.57 & \\
\hline 34 & Ability of effec & 4.87 & 4.54 & 0.32 & $8.10 \%$ & 3.96 & 4.71 & -0.75 & $-18.70 \%$ \\
\hline 35 & $\begin{array}{l}\text { Information a } \\
\text { possibilities }\end{array}$ & & 4.50 & -0.56 & & & 4.33 & 0.51 & \\
\hline 36 & $\begin{array}{l}\text { The end of negotiation and agreem } \\
\text { further procedure }\end{array}$ & 4.10 & 4.75 & -0.65 & $16.14 \%$ & 3.21 & 4.23 & -1.02 & $25.51 \%$ \\
\hline 37. & Requisition of customer contact & 3.98 & 4.52 & -0.55 & $13.64 \%$ & 2.95 & 4.25 & -1.30 & $32.62 \%$ \\
\hline
\end{tabular}

\section{SUMMARY}

The evaluation of service quality within the distribution network of the particular company was carried out by means of research that detected different customer and employee perception of criteria of the suggested service quality standard. This research is described in literature as gap model of service quality. Both groups of respondents made declarations as to the presented text of the standard and noted down in the questionnaire the degree of agreement with formulation of individual criteria and the degree of criteria relevance for customer purchase process.

Significant difference as for criteria perception by customers and employees was identified upon the confrontation of the suggested standard with both groups of respondents. This customer gap in to- 
tal for the whole standard for the degree of agreement amounts to $26.75 \%$, i.e. the value of employee result is by $26.75 \%$ lower than the value of customer perception whereas the target state is the aim to achieve correspondence between employee and customer perception. For the degree of standard relevance the gap amounts to $22.75 \%$ and the same as in the previous case employee perception is lower than customer perception, namely by $22.75 \%$.

The presented text demonstrates that service quality measurement necessitates consideration of all participants in the process of service delivery. The text pays attention to the perception of customers and sales personnel. Perspectives of both groups as for the evaluation of the level of offered services may be more or less different from each other whereas any disparity represents space for possible improvement. Service quality evaluation as it is perceived by customers on the one hand and sales personnel on the other hand implies the identification of possible disparities, which necessitates detection of the causes of this state and choice of appropriate solution.

\section{REFERENCES}

BITNER, M., BOOMS, B. H., MOHR, L.A., 1994: Critical service encounters: the employee's viewpoint. EBSCO [databáze online], Database City Library in Prague (CLP). Journal of Marketing. Vol. 58, s. 95-106. [cit. 2008-02-07]. Available in URL <http://ebsco.mlp. cz/Community.aspx?authtype $=$ ip\&ugt $=24568754$ 6350732161D369188>.

CRONIN, A. M., 2000: Advertising and consumer citizenship: gender, images, and rights. London: Roudledge. ISBN 0-415-22324-5.

CZEPIEL, J., 1990: Service encounters and service relationships: implications for research. In: Hoog, G., Gabbott, M., 1998: Service Industrie Marketing. London: FRANK CASS. ISBN 0-7146-4888-4.

LEVY, M. B., 1995: Retailing management. 2nd ed. London. ISBN 0-0711-4986 4.

LEWIS, B. R., ENTWISTLE, T. W., 1990: Managing the service encounter: a focus on the employee. EBSCO [database online], Database CLP. International Journal of Service Industry Management. Vol. 3, s. 41-52. [cit. 2008-02-07]. Available in URL <http://ebsco. mlp.cz/Community.aspx?authtype=ip\&ugt=2456 8754635073776355632253E5221E361D36913609 364874E788>.
LOVELOCK, CH. H., 2001: Services Marketing. 4th ed. USA: Prwentice Hall. ISBN 0-13-017392-4.

PALMER, A., 2001: Principles of services marketing. 3th ed. England: The McGraw- Hill Companies. ISBN 0-07-709748-3.

REICHHELD, F. et al., 2001: Force Behind Growth, Profits, and Lasting Value, 1st ed. London. ISBN 9781578516872.

SELLERS, P., 1993: What customers really want. San Francisco: Dean Tosvold Jossey-Bass Publishers. ISBN 1-55542-491-0.

SMITH, T., Ed., 1995: Nurturing a customer service culture. London. ISBN 0-7146-4175-8.

SUPRENANT, C. F., SOLOMON, M. R., 1996: Predictability and personalization in the service encounter. EBSCO [database online], Database CLP. Bradford: International Journal of Service Industry Management. Vol. 7. s. 38. [cit. 2008-02-07]. Available in URL http://ebsco.mlp.cz/Community.asp $\mathrm{x}$ ?authtype $=\mathrm{ip} \& u g \mathrm{t}=2456875456.32253 \mathrm{E} 5221 \mathrm{E} 3$ 61D369136088>.

ZEITHAML, V. A., PARASURAMAN, A., BERRY, L. L., 1990: Delivering quality services. 3th ed. USA: The Free Press. ISBN 0-02-935701-2.

URL: < http://www.dek.cz > [cit. 2010-04-10].

Ing. Štěpán Kala, MBA, Ing. Lucie Vokáčová, Ing. Jan Huml, Katedra řízení, Provozně ekonomická fakulta, Česká zemědělská univerzita v Praze, Kamýcká 129, 16521 Praha, Česká republika, e-mail: kalas@pef.czu. cz; vokacova@pef.czu.cz; huml@pef.czu.cz 